\title{
Improvement Potential and Exergy Analyses of Photovoltaic Thermal with and without $\nabla$-absorber Collector
}

\author{
Saprizal Hadisaputra ${ }^{1}$, Muhammad Zohri ${ }^{2}$, Hardani $^{3}$, Ahmad Fudholi $^{4}$ \\ ${ }^{1}$ Faculty of Science and Education, University of Mataram, Indonesia \\ ${ }^{2,4}$ Solar Energy Research Institute (SERI), The National University of Malaysia, 43600 Bangi, Selangor, Malaysia \\ ${ }^{3}$ Polytechnic Medica Farma Husada Mataram, Indonesia \\ ${ }^{2}$ College Computer Information Management (STMIK) Mataram, Indonesia
}

\begin{tabular}{|c|c|}
\hline Article Info & ABSTRACT \\
\hline Article history: & \multirow{7}{*}{$\begin{array}{l}\text { The combination of a solar thermal and photovoltaic system is called } \\
\text { photovoltaic thermal system (PVT). The PVT system with and without } \nabla- \\
\text { absorber has been intended to harvest both hot air and electricity. The hot air } \\
\text { that is produced is used in the cooling process of the photovoltaic panel and } \\
\text { then to improve the efficiency of the photovoltaic panel. The experimental } \\
\text { investigation was conducted at the mass flow rate from } 0.0069 \mathrm{~kg} / \mathrm{s} \text { to } 0.0491 \\
\mathrm{~kg} / \mathrm{s} \text { and solar radiation of } 522 \mathrm{~W} / \mathrm{m}^{2} \text { and } 820 \mathrm{~W} / \mathrm{m}^{2} \text { in the National } \\
\text { University of Malaysia. The using } \nabla \text {-absorber collector increases exergy and } \\
\text { exergy efficiency of PVT system. The improvement potential comparatively } \\
\text { upsurges with cumulative the mass flow rate. }\end{array}$} \\
\hline Received May 14, 2018 & \\
\hline Revised Jul 7, 2018 & \\
\hline Accepted Jul 21, 2018 & \\
\hline Keyword: & \\
\hline$\nabla$-collector & \\
\hline Exergy & \\
\hline
\end{tabular}

Copyright $\odot 2018$ Institute of Advanced Engineering and Science. All rights reserved.

Corresponding Author:

Muhammad Zohri,

College Computer Information Management (STMIK) Mataram, Indonesia.

Email: zohri.ukm@gmail.com

\section{INTRODUCTION}

The use of fossil fuels at this time will be replaced by renewable energy because of its clean and renewable properties. Solar energy has a fundamental role of the energy needs in a country or globally [1]. Solar energy is one of the renewable energy that we can get anywhere. Applications of solar energy can be grouped into two parts, a solar thermal system that converts solar energy into heat energy and photovoltaic systems that convert solar energy into electricity. The combination of a solar thermal and photovoltaic system is called Photovoltaic thermal system (PVT). Since 1970s, Research and Development of PVT system rise because of needs to improve the PV efficiency [2]. Zohri et al. [3] have analyzed exergy and energy performance of PVT system with and without fins absorber with the mathematical model approach. The exergy and energy performance with fins absorber is higher than without fins absorber. Zohri et al. [4] have conducted exergy analysis of PVT system with v-groove collector by mathematical model. The yield of study shows that the effect of solar intensity and the mass flow rate increased exergy efficiency.

Zohri et al. [5] have done a comparison of photovoltaic thermal with and without fins collector. The use of fins collector was higher electrical and thermal performance than without fins collector. The combination of PV panel arrangement with the application of fuzzy reason to maximum power point tracking (MPPT) has been analyzed by Mohammad et al. [6]. The simulation and mathematical model method of the photovoltaic panel have been calculated by Surya and Sai using Matlab-Simulink [7]. The analysis results based on the circuit equation of photovoltaic solar cells with solar radiation and temperature factors. Fudholi et al. [8] has compared exergy and energy analyses of photovoltaic thermal with $\nabla$-groove by the theoretical and experimental approach. The yield of theoretical and experimental was approximately $94 \%$. Fudholi et al. [9] have analyzed solar collector two-pass with and without fins collector. The energy efficiency and cost- 
effective of two-pass with fins are higher than without fins collector. Fudholi et al. [10] have calculated the exergy and improvement potential analysis for the fins double-channel solar collector. The resulting analysis for optimal energy efficiency is about $77 \%$.

Sopian et al. [11] conducted a comparison of one-channel and two-channel PVT system design. They concluded that two-channel has higher efficiency then one-channel. Tiwari and Sodha [12] established the theoretical approach of a combined PVT solar air and water boiler system. They trust that the environment state has very significant for efficiency effect. Bosanac et al. [13] have analyzed the exergy of a PVT system and described that maximum exergy efficiency is about $12 \%$ and the overall energy efficiency is about $60 \%$. Saitoh et al. [14] have conducted the comparison between exergy and energy efficiency of a brine-cooled PVT system in Hokkaido and assumed alike equations as occupied from Fujisawa and Tani [15]. Ajam et al. [16] have calculated the energy and exergy analysis of a solar air heater and established maximum working and design factors of the heater. Sahin et al. [17] have analyzed the exergy of a photovoltaic group based on chemical possible mechanisms. They have compared energy, electrical, exergy performances below assumed climatic and operating conditions.

Many researchers have done analysis exergy efficiency of PVT system solar air collector with the experimental and theoretical approach but the comparison exergy and improvement potential analysis with and without $\nabla$-absorber collector is still less. The performances of PVT with $\nabla$-absorber collectors are characterized by their air temperature rise, thermal and electrical efficiency. The electrical efficiency of PV panel depends on its temperature, which corresponding to the cooling performance. Cooling is a feature that distinguishes PV panel from PVT collector. Therefore, the objective of this study is to analyze the improvement potential and exergy performance of PVT system with and without $\nabla$-absorber collector under solar simulator.

\section{EXPERIMENTAL METHOD AND ANALYSIS}

The PVT system with and without $\nabla$-absorber collector is consists of a PV panel, $\nabla$-absorber collector, fan, an insulator. Ducting used to connect a fan to the PVT system with and without $\nabla$-absorber collector. The tunnel bars were placed on the back surface of PV panel. The 100 Watt PV panel was insulated with monocrystalline. The PVT with $\nabla$-absorber collector evaluated using a specially constructed solar simulator in the laboratory. Solar simulator built using 45 halogen lamps with 500W each lamp. Regulators were used to controlling the solar radiation or brightness of solar simulator. The experiments were conducted under solar radiation of $522 \mathrm{~W} / \mathrm{m} 2$ and $820 \mathrm{~W} / \mathrm{m} 2$, with different mass flow rates from $0.0069 \mathrm{~kg} / \mathrm{s}$ to 0.0491 $\mathrm{kg} / \mathrm{s}$. the electronic load was used to collect data voltage and current with model 8500 from BK precision. An airflow DTA 4000 anemometer was used to determine the airflow velocity. A pyranometer to determine solar radiation and J-type thermocouples connected to multimeter was used. Using ADAM-4019 to record temperature data using computer software automatically made in Solar Energy Research Institute (SERI), the National University of Malaysia. Figure 1 shows the installation of PVT system under simulator.

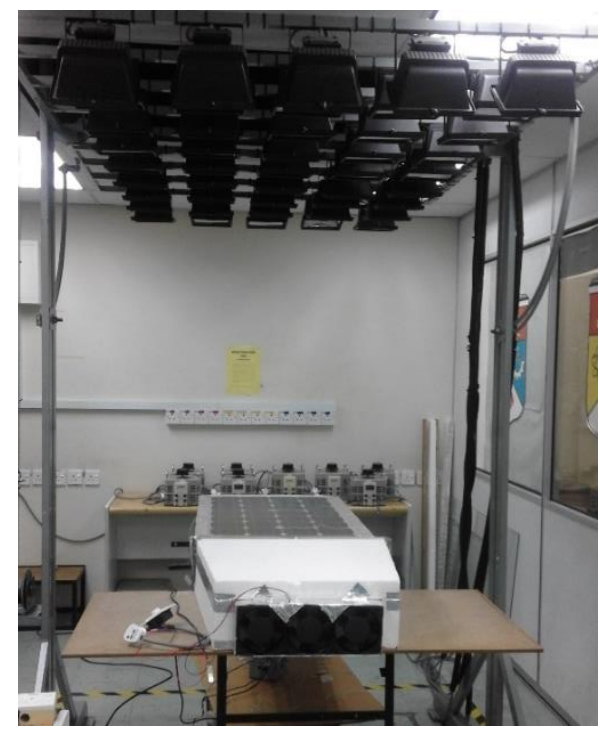

Figure 1. Installation of PVT system with and without $\boldsymbol{\nabla}$-absorber collector under simulator 
Normally, performances of PVT air collector is presented by thermal, electrical, and combined efficiencies, which are functions of parameters such as solar radiation, mass flow rate, ambient, inlet, outlet temperatures. The exergy analysis is based on the second of law of thermodynamic, the general exergy balance is expressed as [18].

$\sum$ Exergy $_{\text {input }}=\sum$ Exergy $_{\text {out }}+\sum$ Exergy $_{\text {dest }}$

Or the equation for exergy is

$\sum$ Exergy $_{\text {out }}=\sum$ Exergy $_{\text {Thermal }}+\sum \operatorname{Exergy}_{P V}$

Where,

$\sum \operatorname{Exergy}_{P V}=\eta_{P V} A_{P V} G$

$\sum$ Exergy $_{\text {Thermal }}=\dot{m} C\left(T_{o}-T_{i}\right)\left(1-\frac{T_{a}+273}{T_{o}+273}\right)$

$\sum$ Exergy $_{\text {input }}=A_{P V} N_{P V} G\left[1-\frac{4}{3}\left(\frac{T_{a}}{T_{S}}\right)+\frac{1}{3}\left(\frac{T_{a}}{T_{S}}\right)^{4}\right]$

$\eta_{\text {Exergy }}=\frac{\text { Exergy }_{\text {out }}}{\text { Exergy }_{\text {in }}}$

Where $\eta_{\text {Exergy }}$ is exergy efficiency, Exergy $y_{\text {out }}$ is output exergy, Exergy $y_{\text {in }}$ is input exergy, $A_{P V}$ is Photovoltaic panel (PV) area, $N_{P V}$ is the number of PV, $G$ is intensity of solar, $T_{s}$ is sun temperature $\left(T_{s}=\right.$ $5777 \mathrm{~K}), T_{a}$ is ambient temperature, $T_{o}, T_{i}$ and $T_{P V}$ are the outlet temperature, the inlet temperature and Photovoltaic panel (PV) temperature respectively ${ }^{\circ} \mathrm{C}$. The exergy destruction $\left(\right.$ Exergy $\left._{\text {dest }}\right)$ or irreversibility may be calculated as follows.

$$
\text { Exergy } y_{\text {dest }}=T_{a} S_{\text {gen }}
$$

Where the entropy group ratio is $S_{g e n}$. Ambient temperature is $T_{a}$. The enhancement of the exergy efficiency is at maximum, while the irreversibility of slightly energy progression is at the lowest condition. The improvement potential (IP) of PVT system is the concept of an exergetic. Improvement Potential is very beneficial instrument to examining method. The IP of PVT system is calculated by [19]

$$
I P=\left(1-\eta_{\text {exergy }}\right) \text { Exergy } y_{\text {dest }}
$$

Where, For Electrical efficiency [20]

$$
\eta_{P V}=\eta_{o}\left[1-0.0045\left(T_{P V}-25\right)\right]
$$

For the temperature coefficient $\beta_{\text {ref }}$ can be written as [21]

$$
\beta_{r e f}=\frac{1}{\left(T_{o}-T_{r e f}\right)}
$$

For Thermal efficiency by following [22].

$$
\eta_{t h}=\dot{m} C\left(T_{o}-T_{i}\right) / I A
$$
Specific heat

The physical properties of air are hypothetical vary linearly with temperature $\left({ }^{\circ} \mathrm{C}\right)$ by Fudholi $[23]$ :

$$
C=1.0057+0.000066(T-27)
$$

Density,

$$
\rho=1.1774-0.00359(T-27)
$$


Thermal conductivity

$k=0.02624+0.0000758(T-27)$

Viscosity

$\mu=[1.983+0.00184(T-27)] 10^{-5}$

The heat transfer coefficient to wind according to Ong [24] is

$$
h_{w}=2.8+3.3 \mathrm{~V}
$$

Where, $h_{w}$ heat transfer coefficient due to wind and $V$ is the wind velocity. The heat transfer coefficient from panel cell to sky.

$$
\begin{aligned}
& h_{r, p v s}=\frac{\sigma \varepsilon_{p v}\left(T_{p v}+T_{S}\right)\left(T_{p v}^{2}+T_{S}^{2}\right)\left(T_{p v}-T_{S}\right)}{T_{p v}-T_{a}} \\
& h_{r, p v b}=\frac{\sigma\left(T_{v p}+T_{b}\right)\left(T_{p v}^{2}+T_{b}^{2}\right)}{\left(\frac{1}{\alpha_{p v}}+\frac{1}{\alpha_{p v}}-1\right)}
\end{aligned}
$$

Where $T_{s}$ is the sky temperature, $T_{c}$ is the photovoltaic panel temperature.

$$
T_{s}=0.0552 T_{a}^{1.5}
$$

\section{RESULTS AND ANALYSIS}

Figure 2 displays the exergy and exergy efficiency versus the difference of mass flow rate of PVT system with and without $\nabla$-absorber collector in solar radiation of $522 \mathrm{~W} / \mathrm{m}^{2}$. With using collector, the exergy is between 45.95 Watt and 51.15 Watt with exergy efficiency of $14-16 \%$. With using without collector, the exergy is between 44.42 Watt and 49.00 Watt with exergy efficiency of $14-15 \%$. The optimum exergy of 51.15 Watt was detected with collector at the mass flow rate of $0.0069 \mathrm{~kg} / \mathrm{s}$ and the minimum exergy of 44.42 Watt was detected without collector at the mass flow rate $0.0491 \mathrm{~kg} / \mathrm{s}$. The exergy and exergy efficiency rises as the mass flow rate drop.

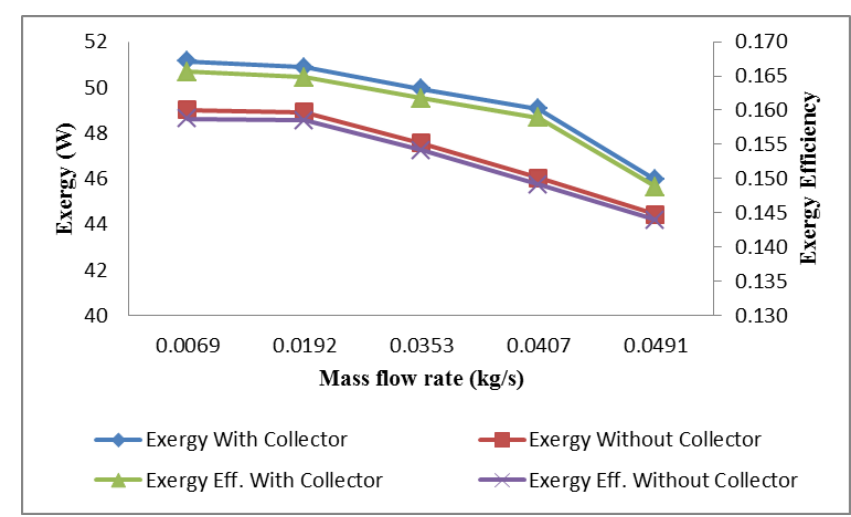

Figure 2. Mass flow rate versus exergy and exergy efficiency in solar radiation of $522 \mathrm{~W} / \mathrm{m}^{2}$

Figure 3 display the mass flow rate versus improvement potential and exergy destruction of PVT system with and without collector. For the solar radiation of $522 \mathrm{~W} / \mathrm{m}^{2}$, the exergy destruction of PVT system with collector is between 257.63 Watt and 262.83 Watt with improvement potential of about 214.95223.72 Watt. With using without collector the exergy destruction of PVT system is between $259.62 \mathrm{~W}$ att and 
264.20 Watt with improvement potential of about 218.40-226.18 Watt. The improvement and exergy destruction congruently rise as the mass flow rate rises.

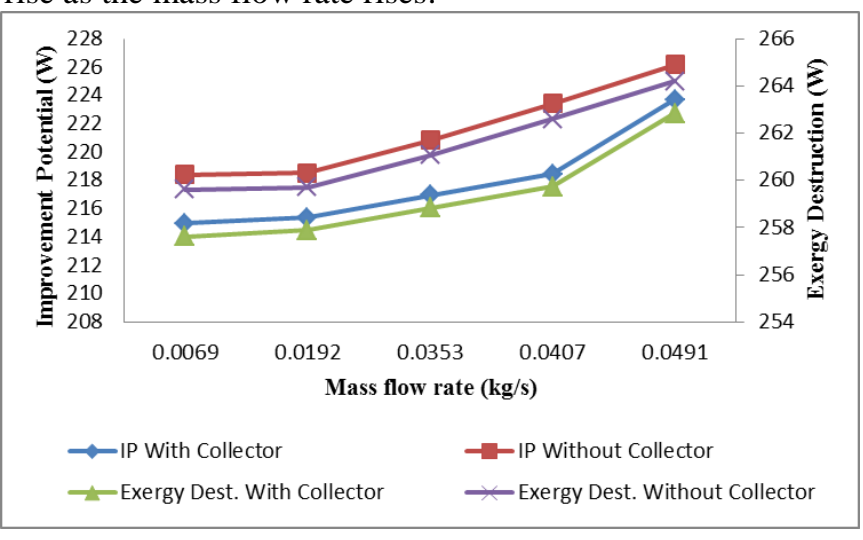

Figure 3. Mass flow rate versus Improvement potential and exergy Destruction in solar radiation of 522 $\mathrm{W} / \mathrm{m}^{2}$

Figure 4 displays the exergy and exergy efficiency versus the difference of mass flow rate of PVT system with and without $\nabla$-absorber collector in solar radiation of $820 \mathrm{~W} / \mathrm{m}^{2}$. With collector, the exergy is between 77.98 Watt and 80.10 Watt with exergy efficiency of 16.1-16.5\%. Without collector, the exergy is between 76.89 Watt and 79.00 Watt with exergy efficiency of 15.9-16.3\%. The optimum exergy of 80.10 Watt was detected with collector at the mass flow rate $0.0069 \mathrm{~kg} / \mathrm{s}$ and the minimum exergy of 76.89 Watt was detected without collector at the mass flow rate $0.0491 \mathrm{~kg} / \mathrm{s}$. The exergy and exergy efficiency rises as the mass flow rate drop.

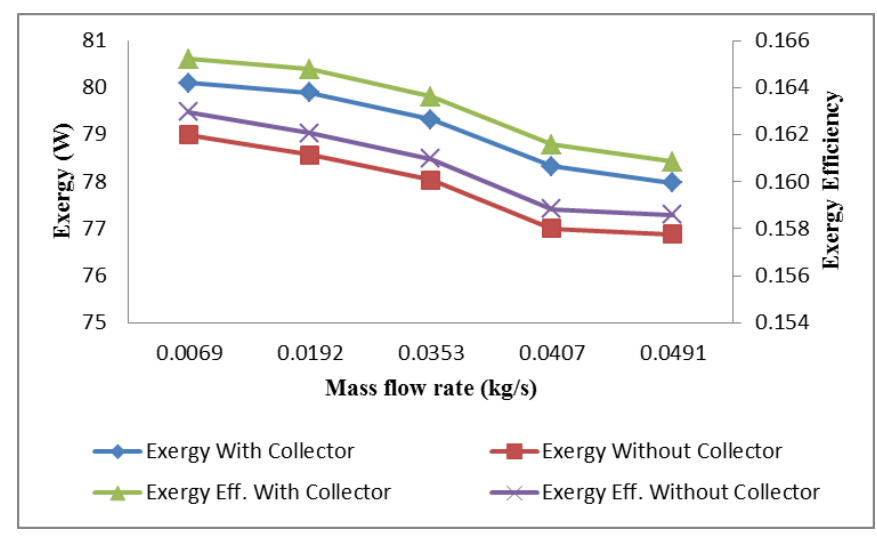

Figure 4. Mass flow rate versus exergy and exergy efficiency in solar radiation of $820 \mathrm{~W} / \mathrm{m}^{2}$

Figure 5 display the mass flow rate versus improvement potential and exergy destruction of PVT system with and without collector. For the solar radiation of $820 \mathrm{~W} / \mathrm{m}^{2}$, the exergy destruction of PVT system with collector is between 404.71 Watt and 406.83 Watt with improvement potential of about 337.84341.39 Watt. With using without collector the exergy destruction of PVT system is between 405.81 Watt and 407.92 Watt with improvement potential of about 339.68-343.23 Watt. The improvement and exergy destruction congruently rise as the mass flow rate rises. 


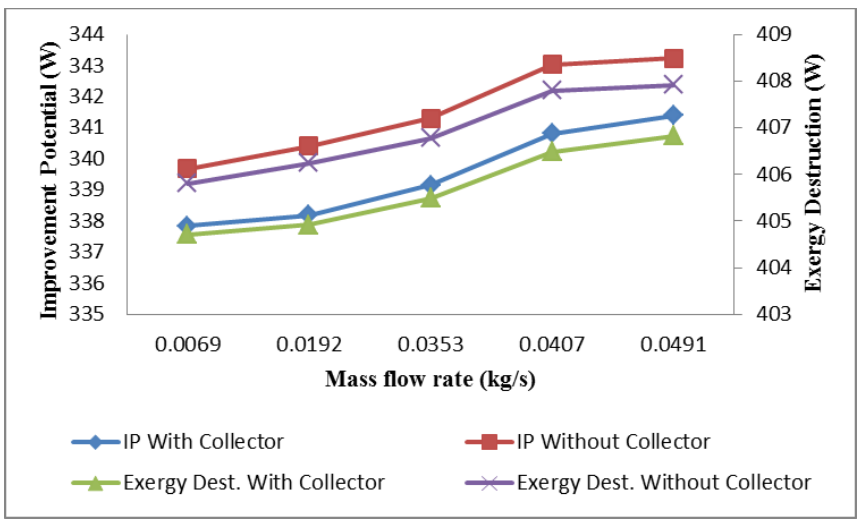

Figure 5. Mass flow rate versus Improvement potential and exergy Destruction In solar radiation of 820 $\mathrm{W} / \mathrm{m}^{2}$

Table 1 shows the comparison of design PVT and solar collector system with other literature. The use of collector is with parallel-plate, solar collector, v-groove and integrated greenhouse system. The present study, v-groove and fins collector are a similar yield of the exergy efficiency. The improvement potential in solar collector or PVT system rises with rising solar intensity and mass flow rate of air. Table 1 shows that fins solar collector design is higher improvement potential than other collector. Fins solar collector used twopass construction and the solar intensity of $790 \mathrm{~W} / \mathrm{m}^{2}$.

Table 1. Comparison of Design PVT System with other Literature

\begin{tabular}{cccc}
\hline Designs of collector & Exergy efficiency & Improvement Potential & References \\
\hline Parallel-plate collector & $12.00 \%-15.00 \%$ & $/$ & {$[25]$} \\
Solar collector & $13.50 \%$ & $/$ & {$[13]$} \\
v-groove collector & $14.00 \%-17.80 \%$ & $/$ & {$[4]$} \\
Fins solar collector & $15.00 \%-17.00 \%$ & $740-780 \mathrm{~W}$ & {$[10]$} \\
Building Integrated PVT system & $12.00 \%-14.00 \%$ & $404 \mathrm{~W}$ & {$[26]$} \\
Present study & $16.50 \%$ & $214.95-343.23 \mathrm{~W}$ & \\
\hline
\end{tabular}

\section{CONCLUSION}

The main conclusions that can be drawn from this study are as follows; a) The exergy and exergy efficiency of PVT system with and without $\nabla$-absorber collector is highly dependent on the mass flow rate; therefore, as the mass flow rate increases then the exergy and exergy efficiency becomes increasingly high. The optimum exergy is about 80.10 Watt was detected with collector at the mass flow rate $0.0069 \mathrm{~kg} / \mathrm{s}$ and exergy efficiency is $16.5 \%$ with collector. The using collector can improve exergy and exergy efficiency of PVT system; b) The improvement potential is between 214.95 Watt and 343.23 Watt with an exergy destruction of $257.63-407.92$ Watt in solar radiation of $522-820 \mathrm{~W} / \mathrm{m}^{2}$. The improvement potential comparatively upsurges with cumulative the mass flow rate and solar intensity.

\section{ACKNOWLEDGEMENTS}

The authors would like to thank the Solar Energy Research Institute (SERI), University Kebangsaan Malaysia for providing the laboratory facilities and technical support. And this research was financially supported by Hibah PDUPT RISTEKDIKTI Indonesia 2018, and their support is gratefully acknowledged.

\section{REFERENCES}

[1] M Zohri, A Fudholi. Keselamatan Tenaga dalam Pandangan Islam (Studi Kasus Negara Indonesia). Fikiran Masyarakat. 2016; 4(2).

[2] M. Zohri, A. Fudholi, M. H. Ruslan, and K. Sopian, "Mathematical modeling of photovoltaic thermal PV/T system with v-groove collector", AIP Conference Proceedings 1862, 030063 (2017); doi: 10.1063/1.4991167

[3] M. Zohri, S. Hadisaputra, A. Fudholi1, "Exergy And Energy Analysis Of Photovoltaic Thermal (PVT) With And Without Fins Collector", ARPN Journal of Engineering and Applied Sciences, Vol. 13, No. 3, February 2018, pp. 803-808 
[4] M. Zohri. Nurato, L. D. Bakti, A. Fudholi, "Exergy Assessment of Photovoltaic Thermal with V-groove Collector Using Theoretical study", TELKOMNIKA, Vol.16, No.2, April 2018, pp. 550 557

[5] M. Zohri, Nurato, Fudholi, A. "Photovoltaic-Thermal (PVT) System with and Without Fins Collector: Theoretical Approach”. International Journal of Power Electronics and Drive System (IJPEDS) Vol. 8, No. 4, pp. 1756-1763;

[6] N. Mohammad, Md. A. Islam, T. Karim, Q. D. Hossain, "Improved solar photovoltaic array model with FLC based maximum power point tracking," International Journal of Electrical and Computer Engineering, vol. 2, pp. 717730, 2012.

[7] J. S. Kumari and Ch. S. Babu, "Mathematical modeling and simulation of photovoltaic cell using Matlab-simulink environment,"International Journal of Electrical and Computer Engineering, vol. 2, pp. 26-34, 2012.

[8] A. Fudholi, M. Zohri, G.L Jin, A. Ibrahim, C.H. Yen, M.Y. Othman, M.H. Ruslan, K. Sopian. "Energy and exergy analyses of photovoltaic thermal collector with $\nabla$-groove", Solar Energy, 2018; 159, 742-750; doi.org/10.1016/j.solener.2017.11.056.

[9] A. Fudholi, K. Sopian, M.H. Ruslan, and M.Y. Othman, "Performance and cost benefits analysis of double-pass solar collector with and without fins", Energy Conversion and Management, 2013; vol. 76, pp. 8-19,

[10] A. Fudholi., K. Sopian, M.Y. Othman, M.H. Ruslan, and B. Bakhtyar, "Energy analysis and improvement potential of finned double-pass solar collector", Energy Conversion and Management, 2013; vol. 75, pp. 234-240.

[11] K. Sopian, K.S. Yigit, H.T. Liu, S. Kakac, T.N. Veziroglu, "Performance analysis of photovoltaic thermal air heaters", Energy Convers. Manage. 1996; 11, 1657-1670.

[12] A. Tiwari, M.S. Sodha, "Performance evaluation of hybrid PV/thermal water/air heating system: a parametric study, Renew. Energy, 2006; 31, 2460-2474.

[13] M. Bosanac, B. Sorensen, K. Ivan, K. Sorensen, N. Bruno, B. Jamal, Photovoltaic/Thermal Solar Collectors and Their Potential in Denmark, Final Report, EFP Project 2003, 1713/00-0014.

[14] H. Saitoh, Y. Hamada, H. Kubota, M. Nakamura, K. Ochifuji, S. Yokoyama, K. Nagano, "Field experiments and analyses on a hybrid solar collector", Applied Thermal Engineering, 2003; 23, 2089-2105

[15] T. Fujisawa, T. Tani, “Annual exergy evaluation on photovoltaic-thermal hybrid collector”, Solar Energy Materials and Solar Cells, 1997; 47, 135-148

[16] H. Ajam, S. Farahat, F. Sarhaddi,, "Exergetic optimization of solar air heaters and comparison with energy analysis", International Journal of Thermodynamics , 2005;8 (4), 183-190.

[17] A. D. Sahin, I. Dincer, M.A. Rosen, "Thermodynamic analysis of solar photovoltaic cell systems", Solar Energy Materials and Solar Cells, 2007; 91,153-159

[18] A. Fudholi, K Sopian, MY Othman, MH Ruslan. Energy and exergy analyses of solar drying system of red seaweed. Energy Build. 2014; 68: 121-129.

[19] H. Caliskan, "Energy, Exergy, environmental, enviro- economic, exergoenvironmental (EXEN) and exergoenviroeconomic (EXENEC) analyses of solar collector", Renewable and Sustainable Energy Reviews, 2017, 69: 488-492.

[20] E. Skoplaki and J. A. Palyvos, "On the temperature dependence of photovoltaic module electrical performance: A review of efficiency/power correlations," Sol. Energy, vol. 83, no. 5, pp. 614-624, 2009.

[21] R. K. Agarwal and H. P. Garg, "Study of a Photovoltaic-Thermal System - - Thermosyphonic Solar Water Heater Combined With Solar Cells," Energy Convers. Manag., vol. 35, no. 7, pp. 605-620, 1994.

[22] T. T. Chow, "A review on photovoltaic/thermal hybrid solar technology," Appl. Energy, vol. 87, no. 2, pp. 365379, 2010.

[23] A. Fudholi, K. Sopian, M. Y. Othman, M. H. Ruslan, and B. Bakhtyar, "Energy analysis and improvement potential of finned double-pass solar collector," Energy Convers. Manag., vol. 75, pp. 234-240, 2013.

[24] K. S. Ong, "Thermal performance of solar air heaters: Mathematical model and solution procedure," Sol. Energy, vol. 55, no. 2, pp. 93-109, 1995.

[25] A. S. Joshi, A Tiwari. Energy and exergy efficiencies of a hybrid photovoltaic thermal (PV/T) air collector. Renew. Energy. 2007; 32: 2223-2241.

[26] A. Ibrahim, A. Fudholi, K. Sopian, M.Y.Othman, M.H. Ruslan, "Efficiency and Improvement potential of building integrated photovoltaic thermal (BIPVT) system”, Energy Conversion and Management, 2014; 77:527-534. 